\title{
Event review: Introduction to classification and description of knapped lithic remains, Madrid, Spain
}

\author{
Nuria Castañeda ${ }^{1,2}$ and Francisco J. Fernández ${ }^{2}$ \\ 1. UMR 8215-Trajectoires Maison Archéologie \& Ethnologie, René-Ginouvès. Allée de l’Université, 21. \\ F-92023, Nanterre Cedex, France. Email: nuriacastanyeda@gmail.com \\ 2. Dibujantes de Arqueología, c. Puerto de Santa María 112. 28043 Madrid, Spain. \\ Email: dibujantesarqueologia@gmail.com
}

From the $28^{\text {th }}$ to $29^{\text {th }}$ of November 2015, Dibujantes de Arqueología held the third edition of the "Introduction to classification and description of knapped lithic materials" in Madrid, Spain. It was an intensive course of 18 hours. Dibujantes de Arqueología is a well-known Spanish business entity of professional archaeologists and specialised drawers in practice since 2003. They have also organised training courses for archaeologists since 2009.

Over the weekend, participants had the opportunity to learn and practice with both real and experimental lithic pieces. Archaeology students usually perceive lithics as boring and a difficult topic because of the old-fashioned way of teaching at universities. Students often have to learn typological lists without having real contact with real pieces. In addition, specialised research papers are complex and inappropriate to learning about lithic technology. The course began by highlighting the importance of classification in lithic studies and how to do it properly with well delimited, coherent and selective categories. The second part dealt with knappable raw material properties and features, and how to recognize natural from intentional items which is the basis of research in lithic technology. During the rest of the course, participants had a chance to practice recognizing by themselves the different parts and attributes of flakes, blades, cores and retouched tools. The final remarks on what to do beyond description, databases, statistics and drawing occupied Sunday afternoon.

It was clear that participants had difficulties in recognizing the different raw materials and alterations, although some of them were more interested in distinguishing different tool types in order to pass their exams. Participants who had already graduated and were actually working in archaeology were more interested in recognizing technical attributes and further implications of lithic technical analyses. Clarity in explanations and personalized attention contributed to participants' learning and improvement.

A new edition of this course will take place on 2016 and will be announced at least two months in advance. More information about courses is available on Google+ (https://plus.google.com/+DibujantesdeArqueología/posts) and Facebook (https://www.facebook.com/dibujantesdearqueologia/). People interested in participating in future courses or holding the course to another city or country can contact the organisers by email at dibujantesarqueologia@gmail.com. ISSN: 2055-0472. URL: http://journals.ed.ac.uk/lithicstudies/

This work is licensed under a Creative Commons Attribution 2.5 UK: Scotland License. 


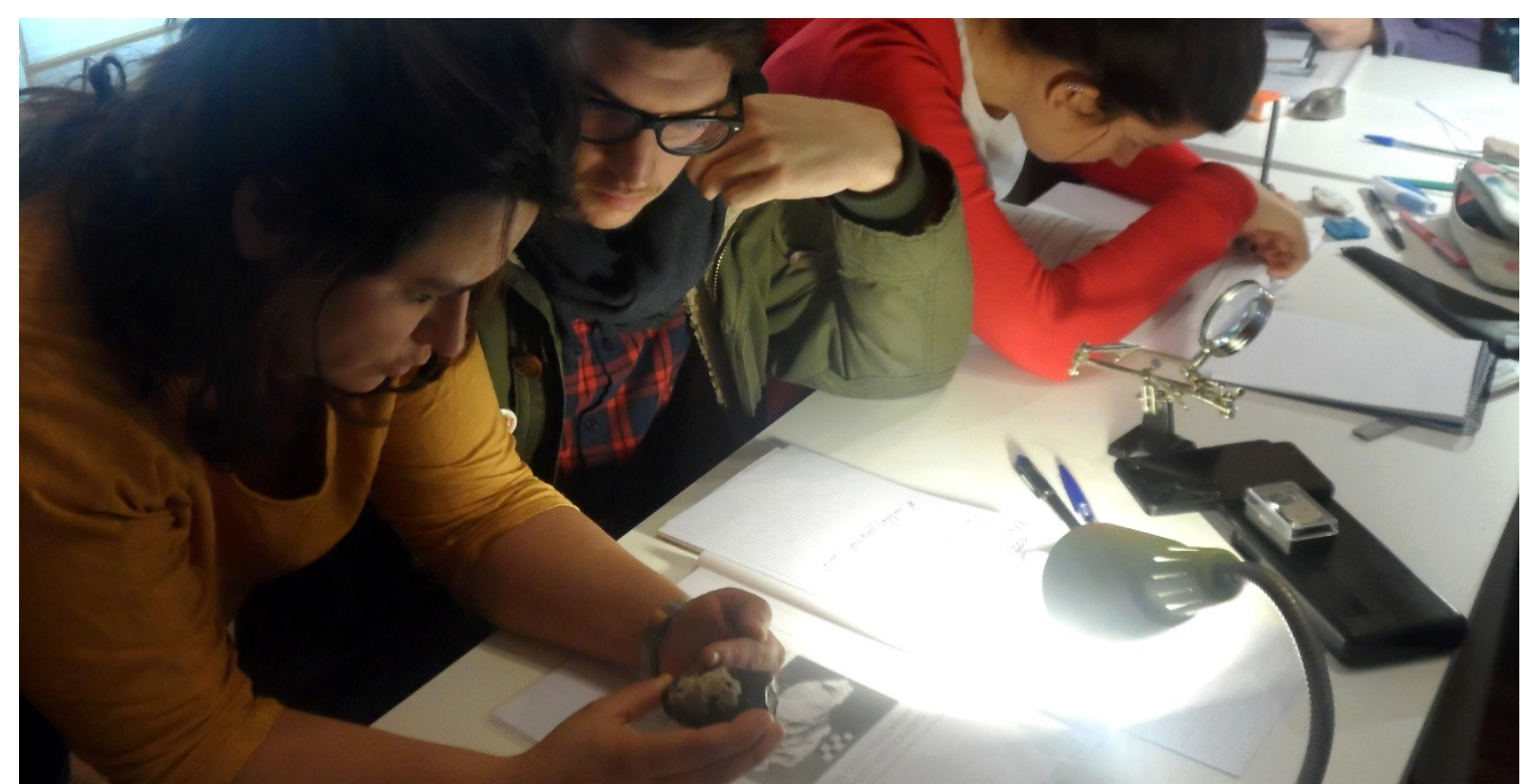

Figure 1. Recognizing the attributes of a lithic core. (Photograph provided by Dibujantes de Arqueología, 2015.)

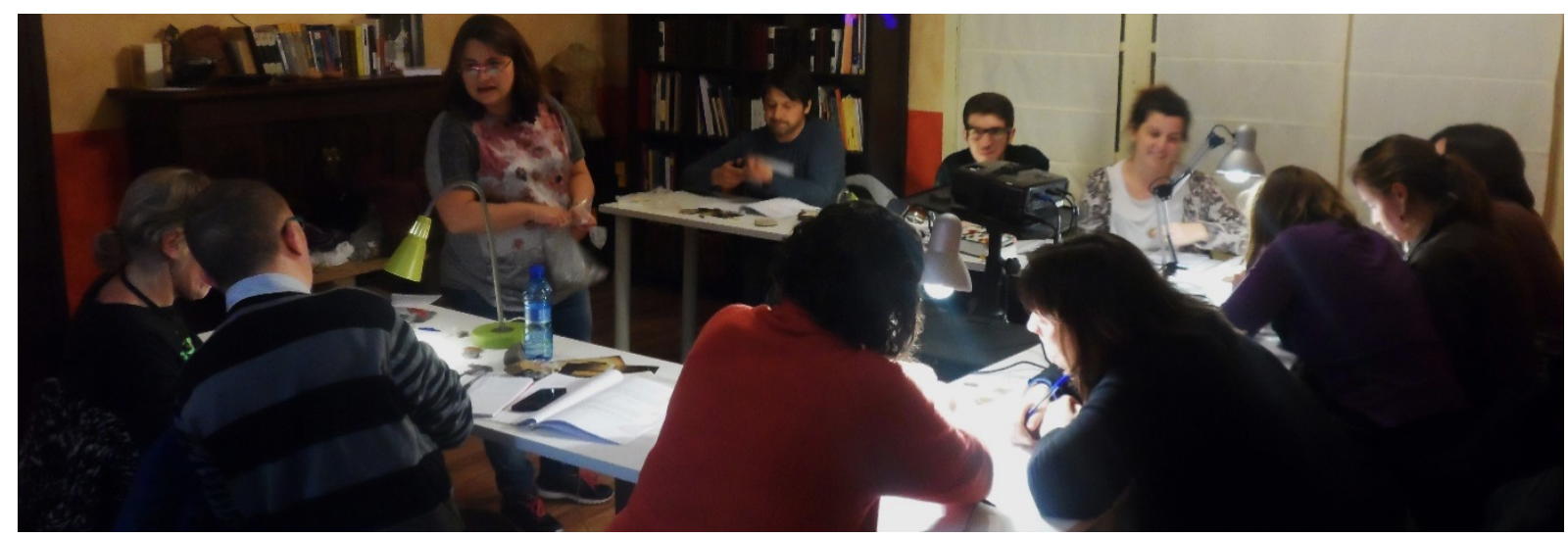

Figure 2. Development of the course. (Photograph provided by Dibujantes de Arqueología, 2015.) 